\title{
HTLV-1 and bronchiectasis in a UK cohort, report and review
}

\author{
Shohreh Honarbakhsh" ${ }^{*}$, Graham P Taylor ${ }^{2}$ \\ From 16th International Conference on Human Retroviruses: HTLV and Related Viruses \\ Montreal, Canada. 26-30 June 2013
}

\section{Background}

Associations between HTLV-1 and pulmonary disease have been reported but causality and risk have not been confirmed. Pulmonary function tests have been routinely offered to new patients attending the UK HTLV service whilst a retrospective case review has been conducted to determine the prevalence of diagnosed bronchiectasis.

\section{Method}

The cohort was categorised into HTLV-1 symptomatic patients (SPs) (ATLL, HAM/TSP, polymyositis and strongyloidiasis) and asymptomatic carriers (ACs). Computerised tomographic (CT) imaging performed was reviewed. In 60 patients disease state was correlated with pulmonary function and HTLV-1 proviral load (VL).

\section{Results}

8/249 ACs and 27/164 SPs had a CT, with productive cough $+/$ - recurrent chest infections the predominant indication. Bronchiectasis was diagnosed in one AC $(1 / 249)$ and 10 SPs (1 polymyositis, 1 ATLL, 8 HAM/ TSP) (10/164, OR 16.10; $\mathrm{p}=0.0084)$. In univariate analysis increased rates of bronchiectasis were seen in HAM/ TSP patients compared with all other categories (OR $14.1 \mathrm{p}<0.0001)$ and non-African/Afro-Caribbean ethnicity subjects (OR 4.2; $\mathrm{p}=0.019$ ) whilst age was significantly associated with bronchiectasis $(\mathrm{p}=0.002)$. PEFR ( $4.96 \mathrm{l} / \mathrm{s}$ vs. $6.77 \mathrm{l} / \mathrm{s} ; \mathrm{p}=0.0003)$, FEV1 (2.22 vs. 2.57; $\mathrm{p}=0.06)$ and $\mathrm{KCO}\left(1.35 \mathrm{~s}^{-1}\right.$ vs. $\left.1.59 \mathrm{~s}^{-1} ; \mathrm{p}=0.0029\right)$ were all lower in SPs (n-27) compared with ACs (n-33) with a negative correlation between VL and PEFR (rr-0.25).

\section{Conclusion}

Bronchiectasis was common in the cohort and therefore HTLV serology should be considered in patients with bronchiectasis. Patients with non-pulmonary HTLV-1associated disease are more likely to have an additional diagnosis of bronchiectasis and obstructive lung disease pattern than ACs suggesting an inflammatory aetiology.

\section{Authors' details}

${ }^{1}$ National Centre for Human Retrovirology, St Mary's Hospital, Imperial College Healthcare NHS Trust, London, UK. ${ }^{2}$ Imperial College London, National Centre for Human Retrovirology, St Mary's Hospital, Imperial College Healthcare NHS Trust, London, UK.

Published: 7 January 2014

\section{doi:10.1186/1742-4690-11-S1-P11}

Cite this article as: Honarbakhsh and Taylor: HTLV-1 and bronchiectasis in a UK cohort, report and review. Retrovirology 2014 11(Suppl 1):P11.

Submit your next manuscript to BioMed Central and take full advantage of:

- Convenient online submission

- Thorough peer review

- No space constraints or color figure charges

- Immediate publication on acceptance

- Inclusion in PubMed, CAS, Scopus and Google Scholar

- Research which is freely available for redistribution 